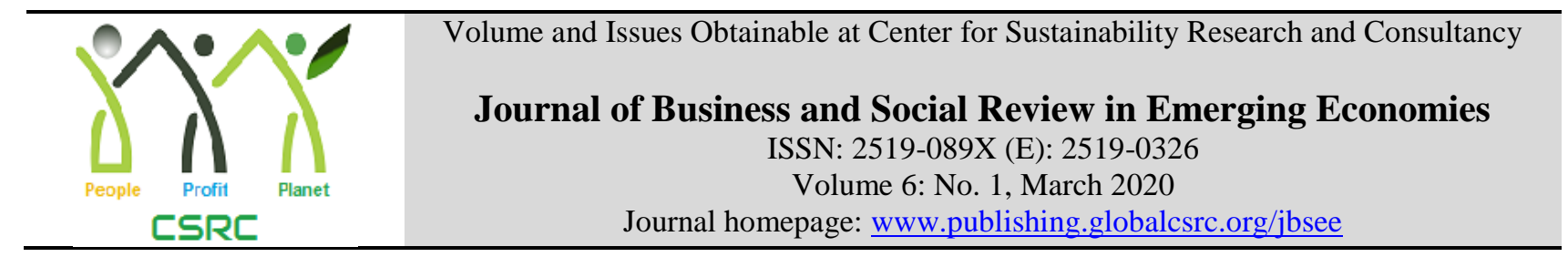

\title{
Evidence of Inflation-Poverty Causality in Nigeria based on the Toda-Yamamoto Dynamic Causality Test
}

\section{${ }^{1}$ Ibrahim Abdulhamid Danlami, ${ }^{2}$ Mohamad Helmi Bin Hidthiir, ${ }^{3}$ Sallahuddin Hassan}

${ }^{1}$ Department of Social Sciences and Administration, School of Continuing Education, Bayero University, Kano, Nigeria, iadanlami.sce@buk.edu.ng

${ }^{2}$ School of Economics Finance and Banking, Universiti Utara Malaysia, m.helmi@uum.edu.my

${ }^{3}$ School of Economics Finance and Banking, Universiti Utara Malaysia, din636@uum.edu.my

\begin{tabular}{l} 
ARTICLE DETAILS \\
\hline History \\
Revised format: February 2020 \\
Available Online: March 2020
\end{tabular}

\section{Keywords}

Inflation,

Money Supply,

Nigeria,

Poverty,

Toda-Yamamoto Causality.

JEL Classification:

E31, E49, H13

\begin{abstract}
Purpose: Rising inflation rate is among major factor contributing towards increasing poverty and its incidence. Though a number of studies have measured this causal relationship, the present study aims at investigating the nature of causality between inflation and poverty with empirical evidence from Nigeria.

Methodology The study has employed the Toda-Yamamoto causality test to investigate the nature of causality between inflation and poverty in Nigeria for the period 1980-2016, with money supply and exchange rate as control variables.

Findings: The results of the study depict a bidirectional causal relationship between inflation and poverty.

Implication: Even though the money supply does not cause poverty directly, it does cause inflation, and inflation in turns causes poverty. Also, the exchange rate does not cause inflation directly, but it does cause poverty, and at the same time, poverty causes inflation. Therefore, the study calls the attention of the policymakers to be cautious in making policies concerning money supply and local currency devaluations (exchange rate) as they cause both inflation and poverty directly and indirectly and affect the social welfare.
\end{abstract}

(C) 2020 The authors, under a Creative Commons AttributionNonCommercial 4.0

Corresponding author's email address: iadanlami.sce@buk.edu.ng

Recommended citation: Danlami,A., Hidthiir, M.H.B., \& Hassan.S. (2020). Evidence of InflationPoverty Causality in Nigeria based on the Toda-Yamamoto Dynamic Causality Test. Journal of Business and Social Review in Emerging Economies, 6(1), 277-286

DOI: $10.26710 /$ jbsee.v6i1.993

\section{Introduction}

High persistent rise in general price level combined with high level of poverty are among the major challenges facing most developing nations. These major challenges coupled with sluggish economic growth and other problems facing developing nation pose welfare deterioration hurdles in most developing societies. Theoretically, one of the consequences of high inflation rate is increasing the rate of poverty. This theoretical presumption has been confirmed by many empirical studies such as Easterly and Fischer (2001), Powers (1995) and Yolanda (2017). On the other hand, Siyan, Adegoriola and Adolphus (2017) confirm that poverty, as well, has a lot of negative consequences to society. One of which, is 
perceived to be causing inflation, though, empirical studies in this regard are inadequate. Ahmad, Bashir and Hussain (2018) maintained that high level of poverty adversely affects the happiness of any society. It is among the crucial issues faced by all nations (Nujum \& Pratiwi, 2018; Rahman, Choudhry \& Farooq, 2018).

Nigeria is among the developing nations, it is in West Africa, and it is experiencing high inflation rate and to some extent the high level of poor people that translate into the high level of poverty. For any developing nation to make meaningful progress, in terms of improving the welfare of its society and economic development, it must make it rates of inflation single-digit, i.e., one to nine percent (Anwar \& Islam, 2011; Danlami, Hidthiir \& Hassan, 2017; Phiri, 2012; Risso \& Sanchez-Carrera, 2009). At the same time, such country should maintain a low level of poverty. On the basis of this argument, inflation and poverty rates of Nigeria are observed, and Figure 1 presents them from 1980 to 2016. In the majority of the periods, the inflation rate is above the threshold of 10 percent that is considered harmful while poverty (as measured by final consumption expenditure per capita growth) in most times is negative which indicates that at most times people are worse-off. The fundamental question is that is it the inflation that granger cause poverty, or it is the poverty that granger cause inflation?

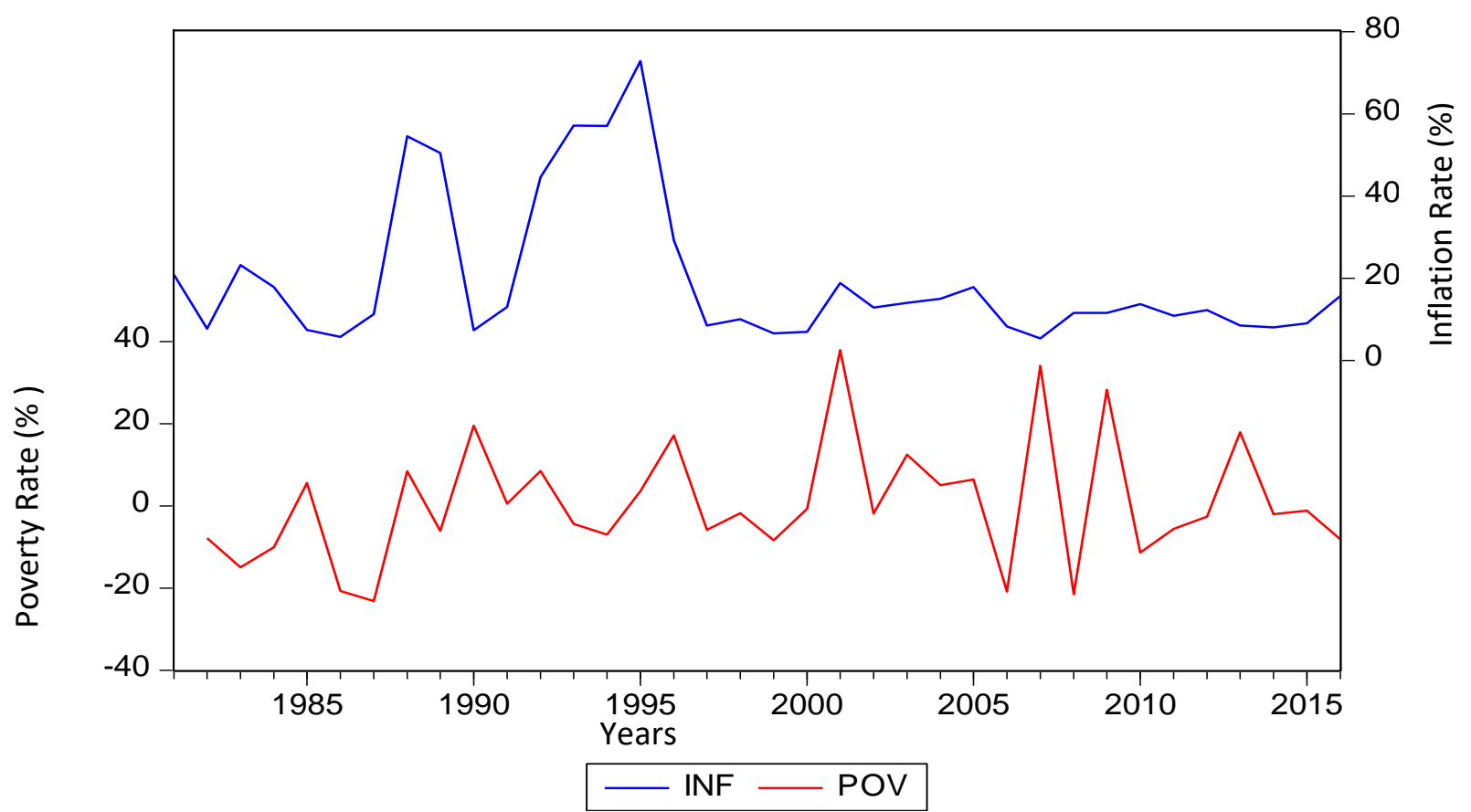

Figure 1, Inflation and Poverty Rate of Nigeria 1980 - 2016.

This study intends to investigate the direction of causality, using the Toda-Yamamoto approach, between inflation and poverty in Nigeria for the period 1980 - 2016. The rest of the paper is as follows; Section two and three presents the literature review and methodology used in the study respectively. The results and findings of the study are presented in Section four of the paper while Section five concludes the study.

\section{Literature Review}

A number of studies exist on relationships between inflation and poverty, investigation the effect of one on another. Though, most of the studies concentrated on checking how inflation affects poverty without investigating the effects of poverty on inflation. Among such studies include Aiyedogbon and Ohwofasa (2012), Chani, Pervaiz, Jan and Ali (2011) and Esterly and Fisher (2001) among others. In another dimension, some studies such as Denssus, Herrera and Hoyos (2008) and Fujii (2013) only concentrated on the effects of food-inflation on poverty. Lastly, Siyan, Adegoriola and Adolphus (2017) used Granger Causality test to investigate the causality direction among them. 
In their quest to investigate the direction of causality between poverty and inflation, Siyan, Adegoriola and Adolphus (2017), use Vector Auto-Regression (VAR) and Granger Causality (GC) test to analyze poverty level, unemployment rate and inflation rate. The result shows that there is bidirectional causality between inflation and poverty as well as between unemployment and poverty. A unidirectional causality is discovered between unemployment and inflation with the causality running from unemployment to inflation. The study used a GC test of causality which is only applicable and valid if the variables are integrated in the same order after unit root test. If the unit root test result shows that the variables are of different level of integration, then the GC test of causality is not valid.

In a controversial finding, Aiyedogbon and Ohwofasa (2012) applied Ordinary Least Squares (OLS) to investigate the impact of inflation on poverty and the results show that inflation reduces poverty as its affects poverty inversely and significantly. On the other hand, Akinbobola and Saibu (2007) countered the above argument and maintained that high inflation rate causes poverty. Similarly, Chani et al., (2011) affirmed that high inflation significantly and positively affects poverty. Furthermore, Easterly and Fischer (2001) maintained that the harmful effects of inflation are more on the poor than the rich, therefore, its effect on poverty is severe. Moreover, Powers (1995) shows that inflation has a high influence on poverty. Nevertheless, Yolanda (2017) also reaffirms that inflation exacerbates poverty in Indonesia.

Meanwhile, following their investigation of the effect of food-inflation on poverty, Dessus, Herrera and Hoyos (2008) pointed-out that food-inflation significantly affects and increases urban poverty. Moreover, Fujii (2013) highlighted that food-inflation adversely and severely affects the poor in general, whether in the agricultural sector or not. Therefore, food-inflation affects the poor harmfully as it increases poverty. Furthermore, Ivanic, Martin and Zaman (2012) investigated the effect of the rise in food prices (foodinflation) on poverty level. Their finding shows that increase in food-prices aggravated poverty. Also, Rehman (2017) affirms that food-inflation decreases poverty in the agricultural sector, i.e., the foodproducers' poverty while increases the poverty in the non-agricultural sector, i.e., the food-consumers' poverty. Thus, the overall effect of food-inflation on poverty is that; inflation aggravates and increases poverty having shown that food-consumers are more than food-producers in numbers.

Nevertheless, Rodriguez-Takeuchi and Imai (2013) asserted that food-inflation increases poverty in Columbia. Also, Son (2008) highlighted that the high level of food-inflation increases the level of poverty. Finally, Walsh and Yu (2012) investigated the effect of food and non-food inflation on poverty. The results show that non-food inflation exacerbates poverty in all sectors (agricultural and nonagricultural sector), whereas, food-inflation reduces the poverty of food-producers (agricultural sector) and increases the poverty of food-consumers (non-agricultural sector).

In terms of methodology, Aiyedogbon and Ohwofasa (2012) used OLS while Akinbobola and Saibu (2007) used VAR. Chani et al., (2011) used the Auto-Regressive Distributed Lag Model (ARDL). Just like Aiyedogbon and Ohwofasa (2012); studies like Powers (1995), Rodriguez-Takeuchi and Imai (2013) and Rehman (2017) as well as Yolanda (2017) all of which used OLS in their respective studies. Meanwhile, Siyan, Adegoriola and Adolphus (2017) utilized the VAR and GC causality test in their studies. A Generalized Method of Moments (GMM) was used by Walsh and Yu (2012) in their study, whereas, Dessus, Herrera and Hoyos (2008) proposed and used Global Income Distribution Dynamic Model (GIDD). Meanwhile Easterly and Fischer (2001) utilized the probit model in their study.

The studies reviewed disclosed that most of the studies concentrated on the effect of inflation on poverty without investigating the causal effect of poverty on inflation. Also, few studies that investigated the direction of causality between poverty and inflation utilized GC causality test which could be invalid if the result of unit root tests reveal the level of integration of the variables used are different from one another. This study is different in the sense that it employs the famous Toda-Yamamoto causality test that provides valid results even if the unit root test result shows that variables are not integrated in the same 
order. It provides a consistent result if the variables are cointegrated or not. The estimation is valid even if it is on a small sample (Toda \& Yamamoto, 1995; Umar \& Dahalan, 2015).

\section{Methodology}

Theoretical Framework: This study will best be understood on the basis of Structural Rigidity Theory, which was developed based on the experience of developing nations. The theory highlighted that; constraint or what they termed as rigidities are the sources of the problems of most developing countries. Problems of rising price level - inflation, poverty, low development level, debt burden and what have you, arise as a result of inherent constraints or rigidities of developing nations. This theory was initially developed by Myrdal (1968), Streeten (1972) and many Latin American economists. Their contribution to the theory is limited the applicability of the theory to Latin American countries, though, such applicability was later generalized to all developing economies by Kirkpatrick and Nixon (1976) (Dwivedi, 2005).

Source of Data: Data were sourced from the World Development Indicators of the World Bank for the period 1980 - 2016. Variables used include: Inflation rate which is in percentage, it measures the persistence of general price changes in an economy and is calculated using the Laspeyres Index, while Household final consumption expenditures per capita growth is used as a measure of poverty. It is the market value of goods and service purchased by a household, it reductions signifies poverty. Also, part of the control variables, Broad Money is used as money supply; and exchange rates (Naira Vis a Vis Dollar) is also used as a control variable.

The Model Specification: On the basis of the specification of Toda and Yamamoto (1995) and Umar and Dahalan (2015) the model of this study is specified in Equation [1] to Equation [4]:

$$
\begin{aligned}
& I N F_{t}=\mathrm{a}_{0}+\sum_{k=1}^{n} \mathrm{a}_{1} I N F_{t-k}+\sum_{j=n+1}^{d \max } \mathrm{a}_{2} I N F_{t-j}+\sum_{k=1}^{n} \mathrm{a}_{3} P O V_{t-k}+\sum_{j=n+1}^{d \max } \mathrm{a}_{4} P O V_{t-j}+\sum_{k=1}^{n} \mathrm{a}_{5} L B R O D_{t-k} \\
& +\sum_{j=n+1}^{d \max } \mathrm{a}_{6} L B R O D_{t-j}+\sum_{k=1}^{n} \mathrm{a}_{7} L E X C_{t-k}+\sum_{j=n+1}^{d \max } \mathrm{a}_{8} L E X C_{t-j} \\
& +\varepsilon_{t} \\
& P O V=\mathrm{a}_{0}+\sum_{k=1}^{n} \beta_{1} I N F_{t-k}+\sum_{j=n+1}^{d \max } \beta_{2} I N F_{t-j}+\sum_{k=1}^{n} \beta_{3} P O V_{t-k}+\sum_{j=n+1}^{d \max } \beta_{4} P O V_{t-j}+\sum_{k=1}^{n} \beta_{5} L B R O D_{t-k} \\
& +\sum_{j=n+1}^{d \max } \beta_{6} L_{B R O D_{t-j}}+\sum_{k=1}^{n} \beta_{7} L E X C_{t-k}+\sum_{j=n+1}^{d \max } \beta_{8} L E X C_{t-j} \\
& +\varepsilon_{t} \\
& L B R O D=\phi_{0}+\sum_{k=1}^{n} \phi_{1} I N F_{t-k}+\sum_{j=n+1}^{d \max } \phi_{2} I N F_{t-j}+\sum_{k=1}^{n} \phi_{3} P O V_{t-k}+\sum_{j=n+1}^{d \max } \phi_{4} P O V_{t-j} \\
& +\sum_{k=1}^{n} \phi_{5} L B R O D_{t-k}+\sum_{j=n+1}^{d \max } \phi_{6} L B R O D_{t-j}+\sum_{k=1}^{n} \phi_{7} L E X C_{t-k}+\sum_{j=n+1}^{d \max } \phi_{8} L E X C_{t-j} \\
& +\varepsilon_{t}
\end{aligned}
$$




$$
\begin{aligned}
L E X C_{t}=\Theta_{0}+ & \sum_{k=1}^{n} \Theta_{1} I N F_{t-k}+\sum_{j=n+1}^{d \max } \Theta_{2} I N F_{t-j}+\sum_{k=1}^{n} \Theta_{3} P O V_{t-k}+\sum_{j=n+1}^{d \max } \Theta_{4} P O V_{t-j}+\sum_{k=1}^{n} \Theta_{5} L B R O D_{t-k} \\
& +\sum_{j=n+1}^{d \max } \Theta_{6} L B R O D_{t-j}+\sum_{k=1}^{d \max } \Theta_{7} L E X C_{t-k}+\sum_{j=n+1} \Theta_{8} L E X C_{t-j} \\
& +\varepsilon_{t}
\end{aligned}
$$

Where: $I N F$ is inflation rate, $P O V$ is poverty, $L B R O D$ is a log of broad money representing money supply, $L E X C$ is a $\log$ of the exchange rate, $\varepsilon$ is error term with its usual properties of independent and identically distributed $\varepsilon \sim$ iid $(0, \delta)$, while $\mathrm{a}_{i}, \beta_{i}, \phi_{i}$ and $\Theta_{i}$ are parameters. The broad money and the exchange rate are in logarithm form.

The Toda-Yamamoto causality test involves two stages; the first stage requires the estimation of Augmented Vector Autoregression (VAR, p+d framework) where parameters are estimated. The second stage involves the estimations of causality by which the results of both causality and that of modified Wald test for weak exogeneity are produced (Toda \& Yamamoto, 1995, Umar \& Dahalan, 2015). The final stage is in form of Wald test where the null hypotheses of the non-existence of causality in the four Equations are: $\mathrm{H}_{0}: \mathrm{a}_{i}=0, \beta_{i}=0, \phi_{i}=0$ and $\theta_{i}=0$ against the alternative hypotheses of existence the of causality $\mathrm{H}_{1}: \mathrm{a}_{i} \neq 0, \beta_{i} \neq 0, \phi_{i} \neq 0$ and $\Theta_{i} \neq 0$.

\section{Results and Findings}

In this section, the findings of the study are presented and discussed. The descriptive statistic is first presented, followed by the result of the unit root test and lag selection, then the result of causality and the section is closed by presenting the results of post-estimation diagnostic checks.

Table 1, presented the descriptive statistics of the variables used in the study. The table shows that the log money supply has the highest average with a value of 27.14 , followed by inflation rate with an average value of 19.60 percent. The average value of the log of exchange rate is 3.29 while that of poverty indicator is 0.56. The maximum value of inflation rate is 72.84 percent and its lowest value is 5.38 percent. The maximum value of poverty indicator is 37.93 while the minimum value is -23.18 . All the variables are normally distributed with the exception of the inflation rate, given their respective JarqueBera statistics and its corresponding probability.

Table 1; Descriptive Statistics of the variables of the Study

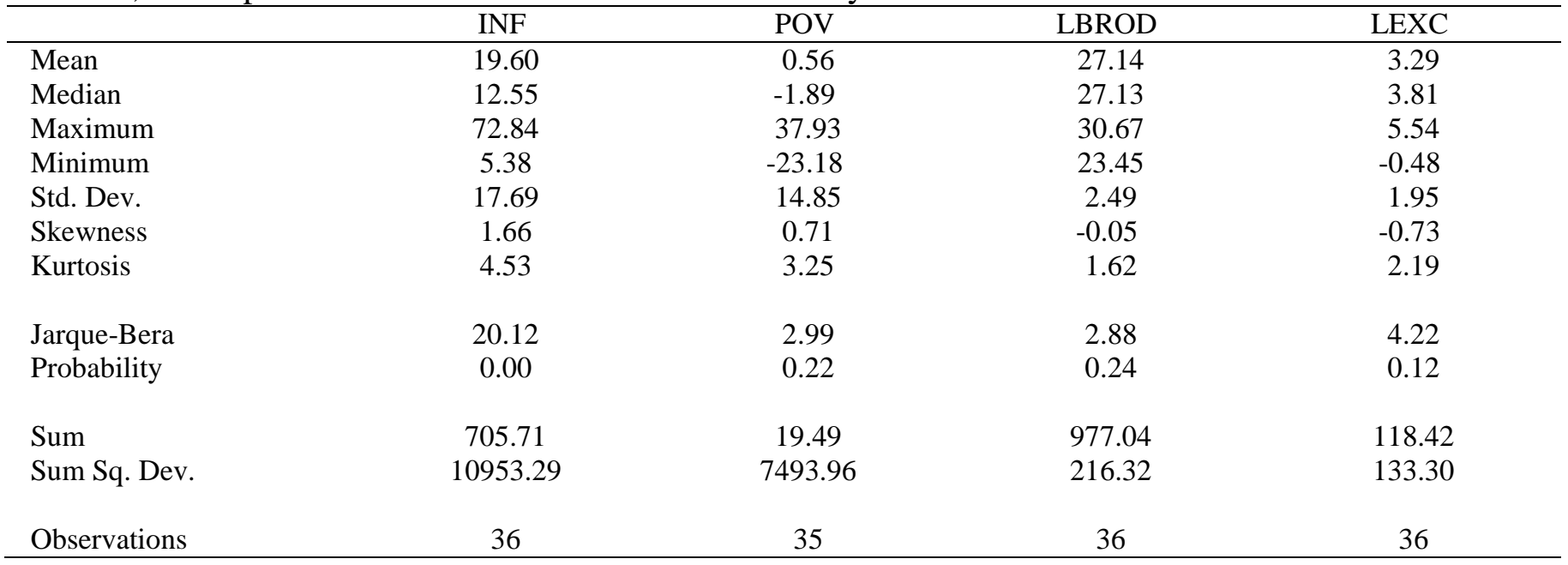


Table 2 presents the results of the unit root test conducted using the famous Augmented Dickey-Fuller (ADF) unit root test. The table shows that all variables are stationary at first difference with the exception of poverty indicator which is stationary at level. This indicates that the variables are not integrated in the same order and therefore, Toda-Yamamoto causality test is among the best method to use for the purpose of identifying the nature and direction of the causality among the variables.

Table 2; Results of ADF Unit Root Tests

\begin{tabular}{llccc}
\hline & \multicolumn{2}{c}{ ADF test at Level } & \multicolumn{2}{c}{ ADF test at 1 ${ }^{\text {st }}$ Diff. } \\
\hline Variable & t-Stat & Probability & t-Stat & Probability \\
\hline Inflation & -2.82 & 0.08 & $-5.42^{*}$ & 0.00 \\
Poverty & $-7.86^{*}$ & 0.00 & - & - \\
Money Supply & -0.66 & 0.84 & $-3.47^{* *}$ & 0.02 \\
Exchange Rate & -1.22 & 0.89 & $-5.36^{*}$ & 0.00 \\
\hline
\end{tabular}

Note: $*$ indicates stationary at one percent and $* *$ indicates stationary at five percent.

Table 3 presents the lag selection criteria. On the basis of the Akaike Information Criterion (AIC), four lags are chosen.

Table 3, Optimal Lag Selection based on General Estimations

\begin{tabular}{ccccccc}
\hline \hline Lag & LogL & LR & FPE & AIC & SC & HQ \\
\hline \hline 0 & -345.3449 & NA & 72183.02 & 22.53838 & 22.72341 & 22.59869 \\
1 & -218.8191 & 212.2368 & 58.41316 & 15.40768 & $16.33284^{*}$ & 15.70926 \\
2 & -197.2290 & $30.64399^{*}$ & $43.13311^{*}$ & 15.04703 & 16.71231 & $15.58987^{*}$ \\
3 & -180.7362 & 19.15289 & 48.62633 & 15.01524 & 17.42064 & 15.79934 \\
4 & -163.7274 & 15.36279 & 62.81075 & $14.95016^{*}$ & 18.09568 & 15.97552 \\
\hline \hline
\end{tabular}

* indicates lag order selected by the criterion

To confirm the optimal lag selection, the test was repeated after estimation using the Toda-Yamamoto Approach, and the result is presented in Table 4. The table shows that the majority of the criteria unanimously indicated the fourth lag as the optimal model.

Table 4, Optimal Lag Selection based on Toda-Yamamoto Estimations

\begin{tabular}{ccccccc}
\hline \hline Lag & LogL & LR & FPE & AIC & SC & HQ \\
\hline \hline 0 & -257.9208 & NA & 1324.914 & 18.52806 & 19.46219 & 18.82689 \\
1 & -204.1720 & 75.24839 & 113.9904 & 16.01147 & 17.69290 & 16.54937 \\
2 & -174.8648 & $33.21476^{*}$ & 55.59510 & 15.12432 & 17.55307 & 15.90130 \\
3 & -159.9606 & 12.91701 & 85.91214 & 15.19737 & 18.37342 & 16.21342 \\
4 & -118.7388 & 24.73308 & $33.20884^{*}$ & $13.51592^{*}$ & $17.43927 *$ & $14.77103^{*}$ \\
\hline \hline
\end{tabular}

* indicates lag order selected by the criterion

Table 5 presents the results of the Toda-Yamamoto causality tests conducted. The table shows that regarding the main variables of the study; inflation and poverty, bidirectional causality exist as poverty causes inflation and at the same time inflation causes poverty. Meanwhile, regarding the causality between the control variables and the main variables, unidirectional causality exists between inflation and money supply with the causality running from money supply to inflation. On one hand, inflation and exchange rate has no causality at the same time zero causality exists between money supply and poverty. On the other hand, unidirectional causality exists between exchange rate and poverty with the causality 
running from exchange rate to poverty. In respect of the causality between the control variables, zero causality exists between the money supply and the exchange rate.

Table 5, The Results of the Toda-Yamamoto Causality Test

\begin{tabular}{llll}
\hline Null Hypothesis & F-statistics & Prob. & Conclusion \\
\hline$P O V$ does not cause $I N F$ & $11.79^{*}$ & 0.02 & Bidirectional \\
$I N F$ does not cause $P O V$ & $11.92^{*}$ & 0.02 & Causality \\
\hline LBROD does not cause $I N F$ & $9.67^{*}$ & 0.04 & Unidirectional \\
$I N F$ does not cause $L B R O D$ & 0.34 & 0.99 & Causality \\
\hline LEXC does not cause $I N F$ & 4.49 & 0.34 & Zero \\
$I N F$ does not cause $L E X C$ & 8.68 & 0.07 & Causality \\
\hline$P O V$ does not cause $L B R O D$ & 0.67 & 0.96 & Zero \\
LBROD does not cause $P O V$ & 7.15 & 0.13 & Causality \\
\hline$P O V$ does not cause $L E X C$ & 1.22 & 0.88 & Unidirectional \\
LEXC does not cause $P O V$ & $38.07^{*}$ & 0.00 & Causality \\
\hline LBROD does not Granger cause $L E X C$ & 1.51 & 0.83 & Zero \\
LEXC does not Granger cause $L B R O D$ & 4.19 & 0.38 & Causality \\
\hline
\end{tabular}

Note: * represent significance at 5 percent.

Table 6 presents the results of the post-estimation diagnostic checks. The table reveals that the estimates are free from serial correlation based on Serial correlation Lagrange Multiplier (LM) test and also free from heteroskedasticity based on Auto-Regressive Conditional Heteroskedasticity (ARCH effect) test, and at the same time, the errors are normally distributed following the Jarque-Bera and its corresponding probability with more than five percent $(0.05)$ values.

Table 6, Post-Estimation Diagnostic Checks

\begin{tabular}{|c|c|c|c|}
\hline \multicolumn{4}{|c|}{ Serial Correlation LM Test } \\
\hline Lags & \multicolumn{2}{|c|}{ LM-Statistics } & Probability \\
\hline 1 & \multicolumn{2}{|c|}{7.943695} & 0.9505 \\
\hline 2 & \multicolumn{2}{|c|}{26.21906} & 0.0510 \\
\hline 3 & \multicolumn{2}{|c|}{14.41399} & 0.5679 \\
\hline 4 & \multicolumn{2}{|c|}{16.55406} & 0.4150 \\
\hline \multicolumn{4}{|c|}{ ARCH Effect Test of Heteroskedasticity } \\
\hline $\begin{array}{c}\text { Dependent } \\
\text { Variable }\end{array}$ & \multicolumn{2}{|c|}{ F-statistic } & Probability \\
\hline Inflation & \multicolumn{2}{|c|}{0.322085} & 0.5750 \\
\hline Poverty & \multicolumn{2}{|c|}{0.250517} & 0.6208 \\
\hline Money Supply & \multicolumn{2}{|c|}{0.489670} & 0.4901 \\
\hline Exchange Rate & \multicolumn{2}{|c|}{1.468195} & 0.2361 \\
\hline \multicolumn{4}{|c|}{ Normality Test } \\
\hline $\begin{array}{l}\text { Dependent } \\
\text { Variable }\end{array}$ & $\begin{array}{l}\text { Skewness } \\
\text { (Prob) }\end{array}$ & $\begin{array}{c}\text { Kurtosis } \\
\text { (Prob) }\end{array}$ & $\begin{array}{c}\text { Jarque-Bera } \\
\text { (prob) }\end{array}$ \\
\hline Inflation & $\begin{array}{l}0.643256 \\
(0.1503)\end{array}$ & $\begin{array}{l}3.166576 \\
(0.8523)\end{array}$ & $\begin{array}{c}2.103573 \\
(0.3493)\end{array}$ \\
\hline Poverty & $\begin{array}{c}-0.230728 \\
(0.6059)\end{array}$ & $\begin{array}{l}2.970643 \\
(0.9738)\end{array}$ & $\begin{array}{c}0.267255 \\
(0.8749)\end{array}$ \\
\hline Money Supply & $\begin{array}{l}0.215396 \\
(0.6301)\end{array}$ & $\begin{array}{l}3.459785 \\
(0.6072)\end{array}$ & $\begin{array}{c}0.496229 \\
(0.7803)\end{array}$ \\
\hline Exchange Rate & $\begin{array}{l}0.196630 \\
(0.6602)\end{array}$ & $\begin{array}{l}2.031016 \\
(0.2787)\end{array}$ & $\begin{array}{c}1.366978 \\
(0.5049)\end{array}$ \\
\hline
\end{tabular}




\section{Conclusion}

This study is conducted to investigate the nature of causality between inflation and poverty in Nigeria, having money supply and exchange rate as control variables using Toda-Yamamoto causality test and time series data for the period 1980 - 2016. The results show that bidirectional causality exists between inflation and poverty, as inflation causes poverty and at the same time poverty causes inflation. None of the variables causes money supply, and none of the variables causes exchange rate. Although, money supply does not directly cause poverty, but it causes inflation, and inflation causes poverty. Also, the exchange rate does not cause inflation, but it does cause poverty, and poverty cause inflation. The results are free from heteroskedasticity and are free from serial correlation with error terms of the models being normally distributed. This is an eye-opener to the policymakers; for them to be cautious in policymaking concerning money supply and currency devaluation, giving the nature of their direct and indirect consequences on both poverty and inflation in the country.

\section{References}

Ahmad, R., Bashir, F., Hussain, A., (2018). Human capital, governance and poverty reduction: A panel data analysis. Review of Economics and Development Studies, 4(1) 103-113.

Aiyedogbon, J. O., \& Ohwofasa, B. O. (2012). Poverty and youth unemployment in Nigeria, 1987-2011. International Journal of Business and Social Science, 3(20), 269 - 279.

Akinbobola, T. O., \& Saibu, M. O. O. (2004). Income inequality, unemployment, and poverty in Nigeria: a vector autoregressive approach. The Journal of Policy Reform, 7(3), 175 - 183.

Anwar, S. \& Islam, I. (2011). Should developing countries target low, single-digit inflation to promote growth and employment? International Labour Organisation, Employment Working Papers No. 87, International Labour Office, Geneva 22.

Chani, D., Irfan, M., Pervaiz, Z., Jan, S. A., Ali, A., \& Chaudhary, A. R. (2011). Poverty, inflation and economic growth: Empirical evidence from Pakistan, World Applied Science Journal, 14(7), 1058 1063.

Danlami, I. A., Hidthirr, M. H. \& Hassan, S. (2017). Dynamic of inflation in developing economies: A quest for conceptual frame-work, IOSR Journal of Humanities and Social Science, 22(10), 53 - 59.

Dessus, S., Herrera, S., \& De Hoyos, R. (2008). The impact of food inflation on urban poverty and its monetary cost: some back-of-the-envelope calculations. Agricultural Economics, 39, 417-429.

Dwivedi, D. N. (2005). Macroeconomics: Theory and policy, $2^{\text {nd }}$ Edition, Tati McGraw-Hill Publishing Company Limited, New Delhi.

Easterly, W., \& Fischer, S. (2001). Inflation and the poor. Journal of Money, Credit and Banking, 33(2), $160-178$.

Fujii, T. (2013). Impact of food inflation on poverty in the Philippines. Food Policy, 39, 13-27.

Ivanic, M., Martin, W., \& Zaman, H. (2012). Estimating the short-run poverty impacts of the 2010-11 surge in food prices. World Development, 40(11), 2302 - 2317.

Kirkpatrick, C. H. \& Nixon, F. I. (1976). The Origins of Inflation in Less Developed Countries. A Selective Review, in Parkin, J. M. and Zis, G. (Eds) (1976). Inflation in Open Economies, Manchester University Press, Manchester.

Myrdal, G. (1968). Asian drama: An inquiry into the poverty of nations, Penguin Books Limited, Harmondsworth, London.

Nujum, S., Pratiwi., F.R., (2018). Poverty alleviation through institutional empowerment of social and economy on poor society in Gowa regency. Review of Economics and Development Studies, 4 (1) 23 29.

Phiri, A. (2012). Threshold effects and inflation persistence in South Africa, Journal of Financial Economic Policy, 4(3) 247 - 269.

Powers, E. T. (1995) Inflation, unemployment, and poverty revisited, Federal Reserve Bank of Cleveland, Economic Review, 31(3), 02 - 13.

Rahman, S., Chaudhry, I.S., Farooq, F., (2018). Gender inequality in education and household poverty in 
Pakistan: A case of Multan district. Review of Economics and Development Studies, 4 (1) 115-126.

Rehman, R. (2017). The effect of increasing food prices on poverty in Pakistan. International Journal of Scientific \& Engineering Research, 8(8), 418 - 423.

Risso, W. A. \& Sanchez-Carrera E. J. (2009). Inflation and Mexican economic growth: long-run relation and threshold effects. Journal of Financial Economic Policy 1(3) 246 - 263.

Rodriguez-Takeuchi, L., \& Imai, K. S. (2013). Food price surges and poverty in urban Colombia: New evidence from household survey data. Food Policy, 43, 227 - 236.

Siyan, P., Adegoriola, A. E., \& Adolphus, J. A. (2016). Unemployment and Inflation: Implication on Poverty Level in Nigeria. Munich Personal RePEc Archive. MPRA paper no. 79765.

Son, H. H. (2008). Has inflation hurt the poor? Regional analysis in the Philippines (No. 112). ERD Working Paper Series.

Streeten, P. (1972). The Frontiers of Development Studies, The Macmillan Press Limited, London and Basingstoke.

Toda, H. Y., \& Yamamoto, T. (1995). Statistical inference in vector autoregressions with possibly integrated processes. Journal of Econometrics, 66(1-2), 225 - 250.

Umar, M., \& Dahalan, J. (2015). Evidence on real exchange rate-inflation causality: An application of the Toda-Yamamoto dynamic Granger causality test. International Business Management, 9(5), 666 675.

Walsh, M. J. P., \& Yu, J. (2012). Inflation and income inequality: Is food inflation different? (No. 12147). International Monetary Fund -IMF working papers WP/12/147.

Yolanda, Y. (2017). Analysis of factors affecting inflation and its impact on human development index and poverty in Indonesia. European Research Studies, 20(4B), 38 - 56. 
